Article

\title{
Oxidation of L-Ascorbic Acid in the Presence of the Copper-Binding Compound from Methanotrophic Bacteria Methylococcus capsulatus (M)
}

\author{
Lidia V. Avdeeva *(D) and Rudolf I. Gvozdev \\ Institute of Problems of Chemical Physics of RAS, Academician Semenov Ave. 1, Chernogolovka 142432, \\ Moscow Region, Russia; rigvozdev@gmail.com \\ * Correspondence: TumanovaLV@yandex.ru
}

Received: 27 August 2020; Accepted: 6 October 2020; Published: 8 October 2020

check for updates

\begin{abstract}
The oxidation of ascorbic acid by air oxygen and hydrogen peroxide in the presence of the copper-binding compound (cbc) from bacteria Methylococcus capsulatus (M) was studied. The rate constant of ascorbic acid oxidation by air oxygen in the presence of the copper complex with cbc from M. capsulatus (M) was shown to be 1.5 times higher than that of the noncatalytic reaction. The rate constant of ascorbic acid oxidation by hydrogen peroxide in the presence of the copper complex with cbc from M. capsulatus (M) decreased by almost one-third compared to the reaction in the absence of the copper complex with cbc. It was assumed that cbc can be involved in a multilevel system of antioxidant protection and can protect a bacterial cell from oxidation stress. Thus, the cbc is mimetic ascorbate oxidase in the oxidation of ascorbic acid by molecular oxygen.
\end{abstract}

Keywords: antioxidant; chalkophores; methanotrophs; L-ascorbic acid; mimetic oxidation

\section{Introduction}

Methanotrophic bacteria (methanotrophs) use methane as a source of carbon and energy and participate in the global carbon cycle. Biological metabolism of methane starts from the activation of the inert $\mathrm{C}-\mathrm{H}$ bond of methane catalyzed by methane monooxygenase (MMO). There are two types of methane monooxygenase: soluble (sMMO) and particulate (pMMO). An interrelation is observed between the copper concentration and the expression of two monooxygenases. Low-molecular-weight copper-binding chromopeptide named methanobactin $(\mathrm{mb})$ is synthesized by methanotrophs to absorb copper [1]. Methanotrophs are widely abundant in nature and live under various conditions. Changes in external factors lead to a series of consequences for a bacterial cell, in particular, in an increase in the level of reactive oxygen species (ROS) in the cell, among which are superoxide $\left(\mathrm{O}_{2}{ }^{-}\right)$, singlet oxygen, hydrogen peroxide $\left(\mathrm{H}_{2} \mathrm{O}_{2}\right)$, hydroxyl radical $\left(\mathrm{OH}^{-}\right)$, and others. Hydrogen peroxide is the most stable of the intermediate products of oxygen reduction but is the least reactive one. It is known that hydrogen peroxide is a reversible inhibitor for $\mathrm{pMMO}$ from Methylosinus trichosporium OB3b under anaerobic conditions [2].

Methanotrophs have several sources of ROS. Of course, ROS are constantly formed in a living cells as a result of various reactions, but they are also formed as products of normal oxygen metabolism. The enhancement of ROS formation in methanotrophs can be a consequence of an increase in the intensity of metabolic processes or rising of cultivation temperature. For example, Methylocaldum szegediense O-12 and Methylococcus capsulatus Bath form ROS at optimum temperatures more intensively than at suboptimum temperatures [3]. Hydrogen peroxide and other ROS are formed due to methane oxidation catalyzed by MMO and as a result of the oxygenase activity of ribulose bisphosphate carboxylase (RubisCO) [2,4]. It is shown that pMMO from M. trichosporium OB3b forms hydrogen peroxide in the presence of duroquinol under anaerobic conditions [2]. 
The specialized antioxidant systems, whose function is reduced to the inactivation of free radicals, maintain the ROS levels in physiological limits. Methanotrophs M. szegediense O-12 and M. capsulatus Bath contain glutathione peroxidase, superoxide dismutase, and cytochrome $c$ peroxidase as the antioxidant system [3]. The pigment melanin in methanotroph $M$. szegediense O-12 characterized by peroxide decomposing activity also has antioxidant properties [5]. It is shown that mb and $\mathrm{Cu}-\mathrm{mb}$ from $M$. trichosporium $\mathrm{OB} 3 \mathrm{~b}$ reduce oxygen to superoxide in the presence of a reductant [6]. The dismutation of superoxide anion $\mathrm{O}_{2}{ }^{-}$to $\mathrm{H}_{2} \mathrm{O}_{2}$ and reduction of $\mathrm{H}_{2} \mathrm{O}_{2}$ to $\mathrm{H}_{2} \mathrm{O}$ without hydroxyl radical $\left(\mathrm{OH}^{*}\right)$ formation can be induced by $\mathrm{mb}$ [6]. It is known that $\mathrm{mb}$ from Methylocystis strain SB2 possess similar properties [1]. This is assumed to be a common property of all mb [1]. However, not all methanotrophs can synthesize $\mathrm{mb}[7,8]$. The existence of genes that encode mb only in several strains of methanotrophs referring to phylum Alphaproteobacteria has been proved [7]. The strains referred to phylum Gammaproteobacteria synthesize another class of chalkophores [9,10]: copper-binding compounds (cbc). The cbc was initially identified in the methanotroph M. capsulatus Bath in association with pMMO [11]. In cells cultured in copper-free medium, the cbc was predominately observed in the extracellular fraction. The cbc isolated from the spent media did not contain copper. Copper-containing cbc was originally proposed as a cofactor of the $\mathrm{pMMO}$, based on the irreversible loss of pMMO activity following separation [11]. The cbc from M. capsulatus Bath and M. album BG8 differed from the mb from $M$. trichosporium $\mathrm{OB} 3 \mathrm{~b}$ in molecular mass and spectral properties. The mb from $M$. trichosporium OB3b can remove $\mathrm{Cu}(\mathrm{I})$ from the $\mathrm{Cu}$-cbc from $M$. capsulatus Bath and M. album BG8 [10]. The EPR and kinetic experiments suggest that $\mathrm{Cu}-\mathrm{cbc}$ is a redox-active chromopeptide that stimulates methane oxidation by pMMO [12]. The explanation and understanding biological properties of the cbc is important task. Therefore, the purpose of this work is to study of the redox active properties of the $c b c$ from Methylococcus capsulatus (M), in particular in the oxidation reaction of L-ascorbic acid $\left(\mathrm{H}_{2} \mathrm{~A}\right)$ in order to highlight the properties of the $\mathrm{cbc}$ for understanding its function in methane oxidation by pMMO and possible participation in the antioxidant system of methanotrophs.

\section{Materials and Methods}

\subsection{Cells Growth}

Cells of M. capsulatus (M) were grown in the flow cultivation regime in an Ankum 2M fermenter (Institute for Biological Instrumentation of the Russian Academy of Sciences, Pushchino, Russia) on a standard mineral medium containing $\mathrm{CuSO}_{4}\left(5 \times 10^{-6} \mathrm{~mol} \mathrm{~L}^{-1}\right)$ at $42{ }^{\circ} \mathrm{C}$ and $\mathrm{pH} 5.6$ as described previously [13]. The cells were sedimented by centrifugation at $6000 \mathrm{~g}$ for $30 \mathrm{~min}$ on an OPn-8 centrifuge (Dastan, Bishkek, Kyrgyzstan).

\subsection{Copper-Binding Compound Isolation}

The isolation of the cbc was conducted from the cultural liquid of M. capsulatus (M) using liquid chromatography on a column packed with Diaion HP20 (Supelco) as previously described [6]. Elution was carried out with $60 \% \mathrm{MeOH}: 40 \% \mathrm{H}_{2} \mathrm{O}$. The obtained preparation of cbc was lyophilized [14]. The cbc complex with copper $(\mathrm{Cu}-\mathrm{cbc})$ was synthesized by the incubation of cbc with an aqueous solution of copper sulphate [9]. Copper titrations were determined by addition of $1 \times 10^{-3} \mathrm{~mol} \mathrm{~L}^{-1}$ or $10 \times 10^{-3} \mathrm{~mol} \mathrm{~L}^{-1}$ aqueous stock solutions of $\mathrm{CuSO}_{4}$ to $5 \times 10^{-3} \mathrm{~mol} \mathrm{~L}^{-1} \mathrm{cbc}$ dissolved in $0.05 \mathrm{M}$ sodium acetate buffer ( $\mathrm{pH}$ 5.5). All titrations were determined at room temperature under aerobic conditions. All glassware was soaked in $1 \mathrm{~N} \mathrm{HNO}_{3}$ for $15 \mathrm{~h}$ then rinsed with copious amounts of distilled-deionized water. Copper was added to solutions of cbc, mixed and incubated for 5 min before spectral determinations [9]. The formation of the complex was monitored by fluorescence quenching method every $45 \mathrm{~s}$ for 5-15 min (Figure S1) using a Cary-Eclipse spectrofluorimeter (Varian, Mulgrave, Australia) [15]. Excitation wavelengths 280, 330, and $400 \mathrm{~nm}$ were used. Between scans, the samples were stored in the dark to avoid photodegradation. 


\subsection{Oxidation of $L$-Ascorbic Acid}

The oxidation of L-ascorbic acid $\left(7 \times 10^{-5} \mathrm{~mol} \mathrm{~L}^{-1}\right)$ by hydrogen peroxide $\left(0.64 \times 10^{-3} \mathrm{~mol} \mathrm{~L}^{-1}\right)$ and air oxygen was conducted in a medium of $0.05 \mathrm{M}$ sodium acetate buffer $(\mathrm{pH} 5.5$, a volume of $3 \mathrm{~mL}$ ) at room temperature (approximately $21^{\circ} \mathrm{C}$ ). The reactions in the presence of $\mathrm{Cu}$-cbc $\left(7 \times 10^{-6} \mathrm{~mol} \mathrm{~L}^{-1}\right)$ or an aqueous solution of copper sulphate $\left(6 \times 10^{-6} \mathrm{~mol} \mathrm{~L}^{-1}\right)$ were carried out in parallel experiments. Solutions of hydrogen peroxide were prepared by the dilution of a $30 \%$ solution of $\mathrm{H}_{2} \mathrm{O}_{2}$. The concentration of hydrogen peroxide was determined by spectrophotometric titration of the reaction of hydrogen peroxide with potassium permanganate in concentrated sulphuric acid $[16,17]$. The solutions of all reagents were freshly prepared in degassed distilled-deionized water and kept in darkness. The oxidation of ascorbic acid was detected by a decrease in the absorbance at $265 \mathrm{~nm}\left(\varepsilon=14,192 \pm 507 \mathrm{~L} \mathrm{~mol}^{-1} \mathrm{~cm}^{-1}\right)$ [17] using a Specord M40 spectrophotometer (Carl Zeis Industrielle Messtechnik $\mathrm{GmbH}$, Oberkochen, Germany) equipped with the software (Institute of Problems of Chemical Physics of RAS, Chernogolovka, Russia) (Figure S2). The reaction was carried out in a quartz cell of the spectrophotometer. The reaction was initiated by ascorbic acid. Time of observation of spectral changes for calculation of kinetic parameters was $t_{1} / 2$. The literature data show that, irrespective of the nature of the oxidizer $\left(\mathrm{O}_{2}\right.$ or $\left.\mathrm{H}_{2} \mathrm{O}_{2}\right)$, which concentration are constant the oxidation of $\mathrm{H}_{2} \mathrm{~A}$ satisfy the pseudo-first-order equation [17]. The observed rate constants $\left(k_{o b s}\right)$ of $\mathrm{H}_{2} \mathrm{~A}$ oxidation were calculated by Equation (1) of the pseudo-first order [17]

$$
k_{o b s}=\frac{1}{t} \ln \left[\frac{c^{0}}{c^{t}}\right]=\frac{1}{t} \ln \left[\frac{A_{0}}{A_{t}}\right],
$$

where $A_{0}, A_{t}$ and $c^{0}, c^{t}$ are the absorbances and concentrations, respectively, at the initial moment and moment $t$.

The half reaction time $\left(t_{1 / 2}\right)$ was calculated by Equation (2).

$$
t_{1 / 2}=\frac{1}{k_{o b s}} \ln \left[\frac{c^{0}}{1 / 2 c^{0}}\right],
$$

The reaction rate of decrease in $\mathrm{H}_{2} \mathrm{~A}\left(w_{\mathrm{H} 2 \mathrm{~A}}\right)$ was calculated by Equation (3).

$$
w_{\mathrm{H}_{2} \mathrm{~A}}=-\frac{\mathrm{d}\left[\mathrm{H}_{2} \mathrm{~A}\right]}{\mathrm{d} t},
$$

\section{Results}

The oxidation reactions of ascorbic acid $\left(\mathrm{H}_{2} \mathrm{~A}\right)$ by air oxygen and hydrogen peroxide were studied to elucidate the oxidase properties and to reveal the role of $\mathrm{cbc}$ in the oxidation of organic compounds. Ascorbic acid $\left(\mathrm{C}_{6} \mathrm{H}_{8} \mathrm{O}_{6}\right)$ is an organic acid with the antioxidant properties acting in chemical and biological systems. Only the L-enantiomer exhibits biological activity. The general scheme of the reaction is presented in Figure 1.<smiles>O=C1O[C@H]([C@H](O)CO)C(O)=C1O</smiles>

Ascorbic acid $\left(\mathrm{H}_{2} \mathrm{~A}\right)$

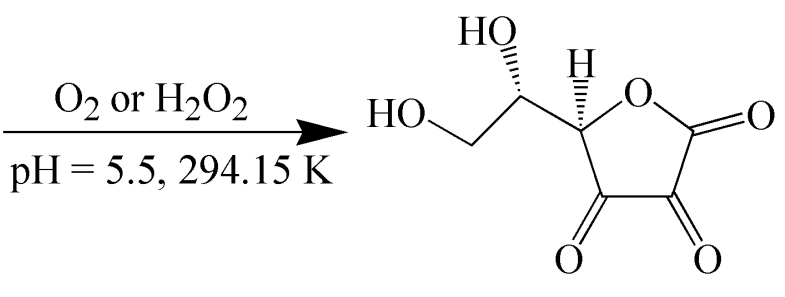

Dehydroascorbic acid (A)

Figure 1. Scheme of ascorbic acid oxidation. 
The oxidation of $\mathrm{H}_{2} \mathrm{~A}$ to dehydroascorbic acid (A) occurs due to the donation of two protons and two electrons. The reaction of $\mathrm{H}_{2} \mathrm{~A}$ oxidation assumes the direct interaction of the ascorbate monoanion $\left(\mathrm{HA}^{-}\right)$with the oxygen. An aqueous solution of $\mathrm{H}_{2} \mathrm{~A}$ is stable in the absence of oxygen, whereas, in air, the solution is stable at $\mathrm{pH} 5-6$ [18]. The oxidation of $\mathrm{H}_{2} \mathrm{~A}$ was carried out in a medium of $0.05 \mathrm{M}$ sodium acetate buffer ( $\mathrm{pH} 5.5$ ) in order to minimize the noncatalytic decomposition of $\mathrm{H}_{2} \mathrm{~A}$. The initial solution of $\mathrm{H}_{2} \mathrm{~A}\left(1 \times 10^{-2} \mathrm{~mol} \mathrm{~L}^{-1}\right)$ used in the work is relatively stable [19]. The study was carried out at a $\mathrm{H}_{2} \mathrm{~A}$ concentration lower by three orders of magnitude $\left(7 \times 10^{-5} \mathrm{~mol} \mathrm{~L}^{-1}\right)$. This solution of $\mathrm{H}_{2} \mathrm{~A}$ is already less stable, and the noncatalytic oxidation of $\mathrm{H}_{2} \mathrm{~A}$ by air oxygen with an appreciable rate is observed (Figure 2, Table 1).

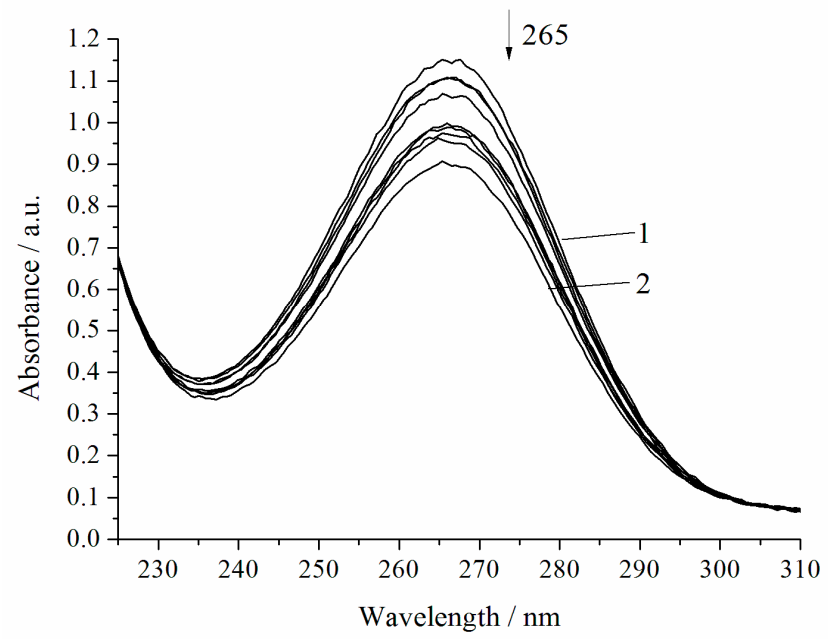

Figure 2. Spectrophotometric changes registered for the oxidation of $\mathrm{H}_{2} \mathrm{~A}\left(c^{0}=7 \times 10^{-5} \mathrm{~mol} \mathrm{~L}^{-1}\right)$ by air at $294.15 \mathrm{~K}$ and $\mathrm{pH} 5.5 ; \mathrm{t}, \mathrm{s}: 1,0 ; 2,1200$. Arrow shows the direction of the spectral evolution.

Table 1. Kinetic parameters for the oxidation of $\mathrm{H}_{2} \mathrm{~A}$ ( $0.05 \mathrm{M}$ sodium acetate buffer, $\left.\mathrm{pH} 5.5,294.15 \mathrm{~K}\right)$.

\begin{tabular}{|c|c|c|c|}
\hline System & $k_{o b s} \times 10^{-4}\left(\mathrm{~s}^{-1}\right)$ & $t_{1 / 2}(\mathrm{~s})$ & $w_{\mathrm{H} 2 \mathrm{~A}} \times 10^{-8}\left(\mathrm{~mol} \mathrm{~L}^{-1} \mathrm{~s}^{-1}\right)$ \\
\hline $\mathrm{H}_{2} \mathrm{~A}+\mathrm{Air}$ & $1.99 \pm 0.14$ & 3497.49 & $1.34 \pm 0.09$ \\
\hline $\mathrm{H}_{2} \mathrm{~A}+\mathrm{Air}+\mathrm{Cu}-\mathrm{cbc}$ & $3.03 \pm 0.15$ & 2287.13 & $1.72 \pm 0.08$ \\
\hline $\mathrm{H}_{2} \mathrm{~A}+\mathrm{Air}+\mathrm{Cu}(\mathrm{II})$ & $48.93 \pm 4.91$ & 141.63 & $14.41 \pm 1.45$ \\
\hline $\mathrm{H}_{2} \mathrm{~A}+\mathrm{H}_{2} \mathrm{O}_{2}$ & $18.47 \pm 1.29$ & 375.20 & $4.75 \pm 0.12$ \\
\hline $\mathrm{H}_{2} \mathrm{~A}+\mathrm{H}_{2} \mathrm{O}_{2}+\mathrm{Cu}-\mathrm{cbc}$ & $11.57 \pm 0.57$ & 598.96 & $3.96 \pm 0.19$ \\
\hline $\mathrm{H}_{2} \mathrm{~A}+\mathrm{H}_{2} \mathrm{O}_{2}+\mathrm{Cu}(\mathrm{II})$ & $98.35 \pm 9.87$ & 70.46 & $14.90 \pm 1.51$ \\
\hline
\end{tabular}

Results are presented as mean values of three replicates \pm SD.

The mechanism of the noncatalytic oxidation of $\mathrm{H}_{2} \mathrm{~A}$ by molecular oxygen in an aqueous solution and in methanol is already known [20]. At a neutral $\mathrm{pH}$, the reaction starts from the interaction of the ascorbate monoanion $\left(\mathrm{HA}^{-}\right)$with an oxygen molecule to form the oxygen adduct of $\mathrm{H}_{2} \mathrm{~A}$. Then, the reaction can proceed via two routes, one of which (most probable) is the disproportionation and formation of superoxide radical $\left(\mathrm{O}_{2}{ }^{-}\right)$and monodehydroascorbic acid radical $\left(\mathrm{HA}^{-}\right)$. The different mechanism via dehydroascorbic acid radical $\left(\mathrm{A}^{-}\right)$formation was proposed earlier for the spontaneous oxidation of $\mathrm{H}_{2} \mathrm{~A}$ [21]. Both mechanisms proposed for $\mathrm{H}_{2} \mathrm{~A}$ oxidation assume the direct interaction of the ascorbate monoanion with the oxygen molecule.

The noncatalytic oxidation of $\mathrm{H}_{2} \mathrm{~A}$ occurs rapidly in the presence of hydrogen peroxide (Figure 3, Table 1). Under the chosen conditions, the complete decomposition of $\mathrm{H}_{2} \mathrm{~A}$ occurs within 20 min. Regardless of the nature of the oxidant (oxygen or hydrogen peroxide), the reactions of $\mathrm{H}_{2} \mathrm{~A}$ oxidation obey the pseudo-first-order equation [17]. 


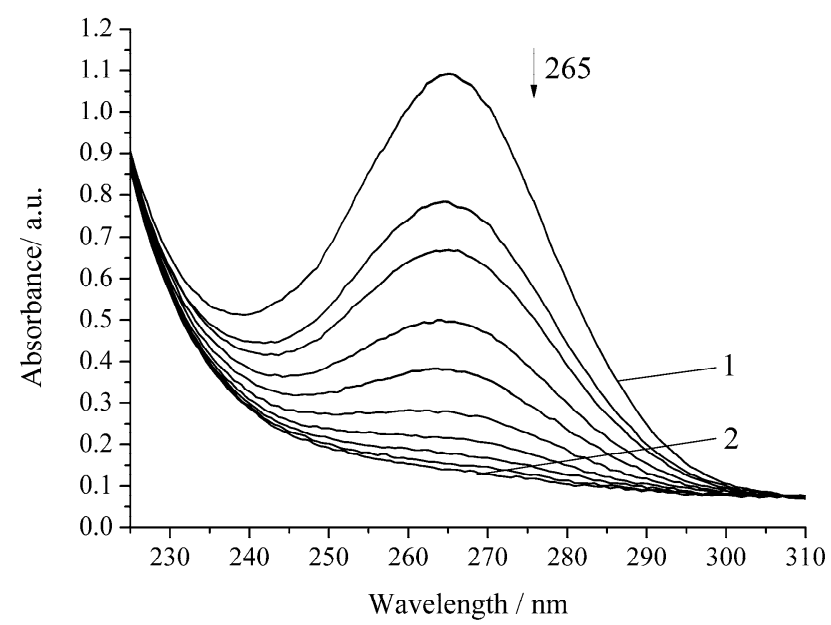

Figure 3. Spectrophotometric changes registered for the oxidation of a solution of $\mathrm{H}_{2} \mathrm{~A}$ $\left(c^{0}=7 \times 10^{-5} \mathrm{~mol} \mathrm{~L}^{-1}\right)$ by $\mathrm{H}_{2} \mathrm{O}_{2}\left(c^{0}=0.64 \times 10^{-3} \mathrm{~mol} \mathrm{~L}^{-1}\right)$ at $294.15 \mathrm{~K}$ and $\mathrm{pH} 5.5 ; \mathrm{t}, \mathrm{s}: 1,0 ; 2,1200$.

Arrow shows the direction of the spectral evolution.

It is known that, on the one hand, $\mathrm{H}_{2} \mathrm{~A}$ is a strong reductant $\left(E_{\mathrm{A} / \mathrm{H} 2 \mathrm{~A}}^{0}=0.390 \mathrm{~V}\right.$ vs. N.H.E. $)$ and, on the other hand, a weak acid dissociating via two steps, as follows [18]:

$$
\begin{aligned}
& \mathrm{H}_{2} \mathrm{~A} \leftrightarrow \mathrm{HA}^{-}+\mathrm{H}^{+}, \mathrm{pK}_{1}=4.04 \\
& \mathrm{HA}^{-} \leftrightarrow \mathrm{A}^{2-}+\mathrm{H}^{+}, \mathrm{p} K_{2}=11.34
\end{aligned}
$$

where $\mathrm{H}_{2} \mathrm{~A}$ is ascorbic acid, $\mathrm{HA}^{-}$is ascorbate monoanion, and $\mathrm{A}^{2-}$ is dehydroascorbic acid.

Therefore, at $\mathrm{pH} 5.5, \mathrm{H}_{2} \mathrm{~A}$ almost completely exists in the solution as an ascorbate monoanion $\left(\mathrm{HA}^{-}\right)$. All three forms of $\mathrm{H}_{2} \mathrm{~A}$ are active, and the activity order is the following: $\mathrm{H}_{2} \mathrm{~A}<\mathrm{HA}^{-}<\mathrm{A}^{2-}$ [22] The ascorbate monoanion $\left(\mathrm{HA}^{-}\right)$is fairly rapidly dissociated to dehydroascorbic acid $\left(\mathrm{A}^{2-}\right)$, which determines the instability of $\mathrm{H}_{2} \mathrm{~A}$ (Figure 2).

In the presence of $\mathrm{Cu}$-cbc from $M$. capsulatus $(\mathrm{M})$, the oxidation rate of $\mathrm{H}_{2} \mathrm{~A}$ by air oxygen increases by 1.5 times compared to the noncatalytic oxidation of $\mathrm{H}_{2} \mathrm{~A}$ (Figure 4 , Table 1 ).

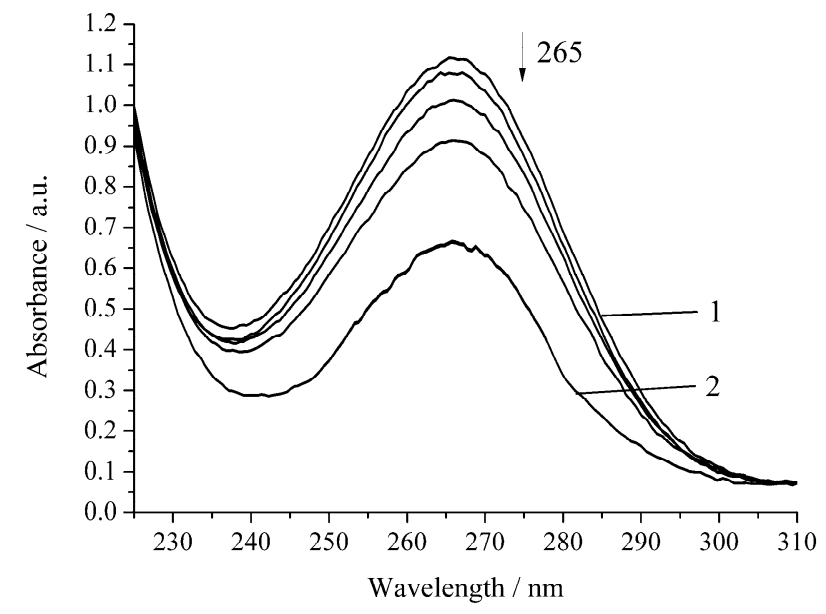

Figure 4. Spectrophotometric changes registered for the oxidation of a solution of $\mathrm{H}_{2} \mathrm{~A}$ $\left(c^{0}=7 \times 10^{-5} \mathrm{~mol} \mathrm{~L}^{-1}\right)$ by air oxygen in the presence of $\mathrm{Cu}-\mathrm{cbc}\left(7 \times 10^{-6} \mathrm{~mol} \mathrm{~L}^{-1}\right)$ from M. capsulatus (M) at $294.15 \mathrm{~K}$ and pH 5.5; t, s: 1, 0; 2, 1620. Arrow shows the direction of the spectral evolution.

However, the inhibition of the reaction is observed for the oxidation of $\mathrm{H}_{2} \mathrm{~A}$ by hydrogen peroxide in the presence of $\mathrm{Cu}$-cbc (Figure 5, Table 1). 


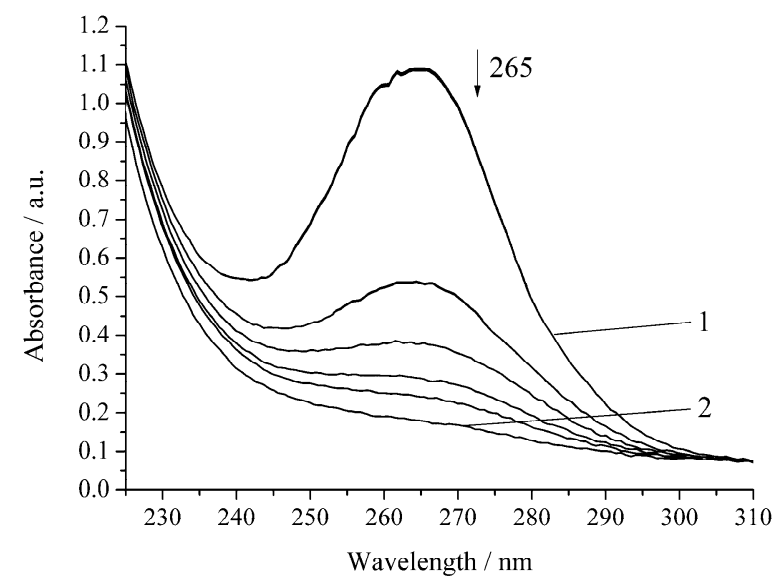

Figure 5. Spectrophotometric changes registered for the oxidation of a solution of $\mathrm{H}_{2} \mathrm{~A}$ $\left(c^{0}=7 \times 10^{-5} \mathrm{~mol} \mathrm{~L}^{-1}\right)$ by $\mathrm{H}_{2} \mathrm{O}_{2}\left(c^{0}=0.64 \times 10^{-3} \mathrm{~mol} \mathrm{~L}^{-1}\right)$ in the presence of $\mathrm{Cu}-\mathrm{cbc}\left(7 \times 10^{-6} \mathrm{~mol} \mathrm{~L}^{-1}\right)$ from M. capsulatus (M) at $294.15 \mathrm{~K}$ and $\mathrm{pH} 5.5 ; \mathrm{t}, \mathrm{s:} 1,0 ; 2,1140$. Arrow shows the direction of the spectral evolution.

The oxidation rate of $\mathrm{H}_{2} \mathrm{~A}$ by hydrogen peroxide in the presence of $\mathrm{Cu}-\mathrm{cbc}$ is higher than that for oxidation by air oxygen as in the case of the noncatalytic oxidation of $\mathrm{H}_{2} \mathrm{~A}$. However, the rate constant is lower by $37 \%$ than that of the similar reaction without $\mathrm{Cu}-\mathrm{cbc}$ (Table 1). This reaction was carried out in the presence of the copper complex with cbc obtained by the titration of a solution of $\mathrm{cbc}$ with a solution of copper sulphate. It is known that transition metals $(\mathrm{Cu}(\mathrm{II}), \mathrm{Fe}(\mathrm{II}), \mathrm{V}(\mathrm{V}), \mathrm{Cr}(\mathrm{VI})$, and $\mathrm{Mn}(\mathrm{II}))$ accelerate the oxidation of $\mathrm{H}_{2} \mathrm{~A}$ [23]. Copper has the highest activity among the studied metals [21,23]. It is known that copper also catalyzes the oxidation of $\mathrm{H}_{2} \mathrm{~A}$ in an acidic medium by peroxomonosulphate [24] and peroxodiphosphate [25]. The oxidation of $\mathrm{H}_{2} \mathrm{~A}$ by copper(II) in an alkaline solution was studied by the chemiluminescence method using a luminol/copper(II) system. Oxygen and halide anions $\left(\mathrm{Cl}^{-}, \mathrm{Br}^{-}\right.$, and $\left.\mathrm{I}^{-}\right)$significantly catalyze this oxidation of $\mathrm{H}_{2} \mathrm{~A}$ to form ROS $\left(\mathrm{H}_{2} \mathrm{O}_{2}\right.$ and $\left.\mathrm{O}_{2}^{-}\right)$[26]. In order to exclude that, the observed effect (Figures 4 and 5) can be induced by copper cations (added for formation of the $\mathrm{Cu}$-cbc complex); the oxidation of $\mathrm{H}_{2} \mathrm{~A}$ was conducted in the presence of copper(II) sulphate under the same conditions (Figures 6 and 7).

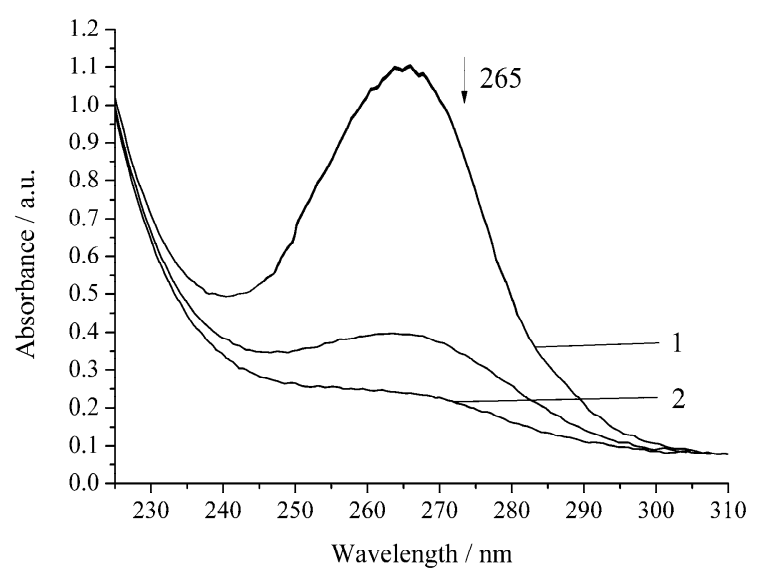

Figure 6. Spectrophotometric changes registered for the oxidation of a solution of $\mathrm{H}_{2} \mathrm{~A}$ $\left(c^{0}=7 \times 10^{-5} \mathrm{~mol} \mathrm{~L}^{-1}\right)$ by air oxygen in the presence of $\mathrm{Cu}(\mathrm{II})\left(6 \times 10^{-6} \mathrm{~mol} \mathrm{~L}^{-1}\right)$ at $294.15 \mathrm{~K}$ and $\mathrm{pH}$ $5.5 ; \mathrm{t}, \mathrm{s}: 1,0 ; 2,240$. Arrow shows the direction of the spectral evolution. 


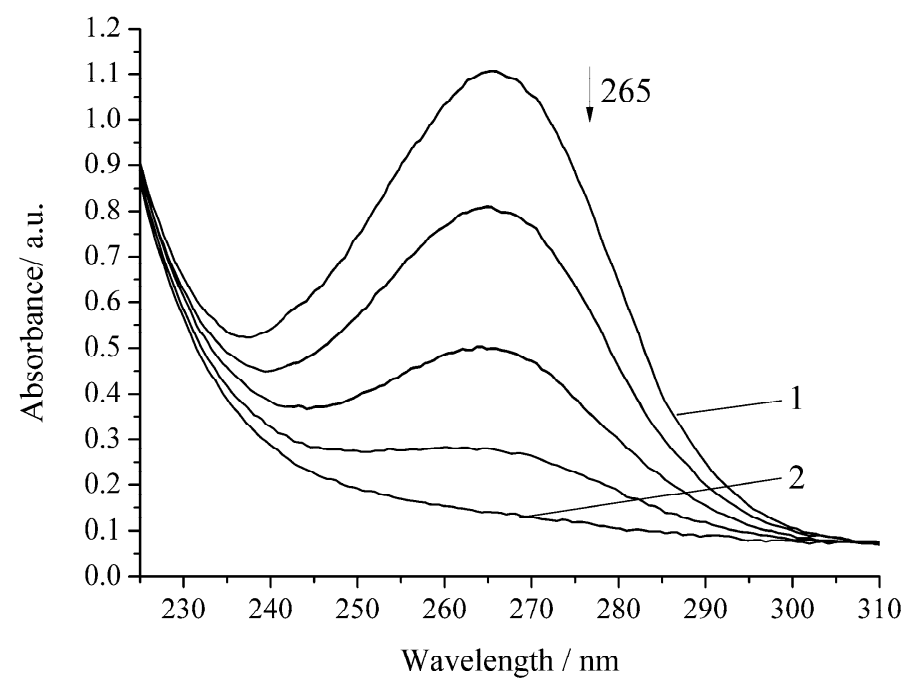

Figure 7. Spectrophotometric changes registered for the oxidation of a solution of $\mathrm{H}_{2} \mathrm{~A}$ $\left(c^{0}=7 \times 10^{-5} \mathrm{~mol} \mathrm{~L}^{-1}\right)$ by $\mathrm{H}_{2} \mathrm{O}_{2}\left(c^{0}=0.64 \times 10^{-3} \mathrm{~mol} \mathrm{~L}^{-1}\right)$ in the presence of $\mathrm{Cu}(\mathrm{II})\left(6 \times 10^{-6} \mathrm{~mol} \mathrm{~L}^{-1}\right)$ at $294.15 \mathrm{~K}$ and $\mathrm{pH} 5.5 ; \mathrm{t}, \mathrm{s}: 1,0 ; 2,180$. Arrow shows the direction of the spectral evolution.

In the presence of copper(II), high rates for $\mathrm{H}_{2} \mathrm{~A}$ oxidation are observed in the cases of both air oxygen and hydrogen peroxide (Table 1). It is known that copper(II) forms complex(es) with $\mathrm{H}_{2} \mathrm{~A}$, which was confirmed kinetically [25]. The mechanism was proposed for the catalytic oxidation of $\mathrm{H}_{2} \mathrm{~A}$ by copper cations [21]. The reaction mechanism of the catalytic oxidation of $\mathrm{H}_{2} \mathrm{~A}$ is accompanied by the formation of radical species, as is the case for noncatalytic oxidation.

The numerical values of the kinetic parameters for $\mathrm{H}_{2} \mathrm{~A}$ oxidation obtained in this paper are presented in Table 1.

The reaction of full $\mathrm{H}_{2} \mathrm{~A}$ oxidation in all the studied systems takes place during different times (Figures 2-7) and have different reaction rates $\left(w_{\mathrm{H} 2 \mathrm{~A}}\right)$ of $\mathrm{H}_{2} \mathrm{~A}$ oxidation and different half-rotation times $\left(t_{1 / 2}\right)$, which do not depend on the initial concentration of the $\mathrm{H}_{2} \mathrm{~A}$ (Table 1). The time of half-rotation of the $\mathrm{H}_{2} \mathrm{~A}$ by air oxygen without $\mathrm{Cu}-\mathrm{cbc}$ is maximum and decreases by $35 \%$ in the presence of $\mathrm{Cu}$-cbc. The data in Table 1 show that the oxidation of $\mathrm{H}_{2} \mathrm{~A}$ by hydrogen peroxide is characterized by the rate constant exceeding that of the analogous oxygen oxidation by approximately ten times. This can be explained by a high activity of peroxide radicals [27]. Among all reactions studied in this work, the highest catalytic effect was observed with copper cations for the oxidation by both oxygen and hydrogen peroxide (Table 1). The "theoretical" concentration of free copper if there was no binding of copper with cbc in the case of the reactions with $\mathrm{Cu}-\mathrm{cbc}$ (the copper concentration calculated from the amount of copper consumed to the titration of a solution of cbc, taking into account all dilutions) should be $7 \times 10^{-6} \mathrm{~mol} \mathrm{~L}^{-1}$, which is comparable with the copper concentration used in the studied reactions $\left(6 \times 10^{-6} \mathrm{~mol} \mathrm{~L}^{-1}\right)$ (Figures 6 and 7). However, the catalytic effect of copper cations is much higher than that of $\mathrm{Cu}$-cbc (Table 1). The activity of copper(II) in the oxidation of $\mathrm{H}_{2} \mathrm{~A}$ can be caused by three factors. First, copper(II) cations in a solution are more accessible than $\mathrm{Cu}$-cbc for the formation of intermediate compounds with the reagents [19]. Second, copper(II) cations in this concentration are not active in the decomposition of hydrogen peroxide and almost do not change the concentration of the latter [19]. Third, differences are possible in the mechanisms of $\mathrm{H}_{2} \mathrm{~A}$ oxidation by copper cations and $\mathrm{Cu}-\mathrm{cbc}$.

The mechanism and kinetics of $\mathrm{H}_{2} \mathrm{~A}$ oxidation by different oxidizing agents and catalysts are the subjects of extensive studies [19-26,28]. A considerable contribution of radical reactions to the oxidation of $\mathrm{H}_{2} \mathrm{~A}$ is presently doubtless. However, no unambiguous mechanism was proposed for either hydrogen peroxide decomposition or $\mathrm{H}_{2} \mathrm{~A}$ oxidation. This is due to the fact that many factors affect these processes: $\mathrm{pH}$ of the solution, temperature, impurities. The oxidation of $\mathrm{H}_{2} \mathrm{~A}$ 
is substantially accelerated in the presence of cations and complexes of $\mathrm{Co}(\mathrm{II}), \mathrm{Fe}(\mathrm{II}), \mathrm{Cu}(\mathrm{II}), \mathrm{Mn}$ (II), and $\mathrm{Ni}(\mathrm{II})[19,21-26,28]$. Other copper complexes exhibiting the catalytic properties in reaction oxidation of organic compounds are also known. The activity of the complexes $\left[\mathrm{Cu}\left(\mathrm{L}^{1} / \mathrm{L}^{2}\right)\right]-\left[\mathrm{MCl}_{4}\right]$ in the oxidation of $\mathrm{H}_{2} \mathrm{~A}$ by molecular oxygen in an aqueous solution was studied [17]. It is also known that copper phthalocyanine $\left(\mathrm{CuPcCl}_{15}\right)$ catalyzes cyclohexane oxidation by hydrogen peroxide to cyclohexanol and cyclohexanone [29]. The copper(II) salts (acetate, perchlorate, and chloride) catalyze the oxidation of benzene by hydrogen peroxide to phenol and quinine [30]. However, $\mathrm{Cu}$-cbc give the inverse effect, and inhibition of reaction $\mathrm{H}_{2} \mathrm{~A}$ oxidation by hydrogen peroxide was observed (Table 1 ).

Now, it is difficult to propose a mechanism of the catalytic effect of $\mathrm{Cu}-\mathrm{cbc}$ on the oxidation of $\mathrm{H}_{2} \mathrm{~A}$. Probably, $\mathrm{Cu}$-cbc catalyzes $\mathrm{H}_{2} \mathrm{~A}$ oxidation by oxygen via a mechanism different from the mechanism of catalyzed by the copper(II) cations and its complexes. This is indicated by the inhibition of a similar reaction of $\mathrm{H}_{2} \mathrm{~A}$ oxidation by hydrogen peroxide, because this reaction is catalyzed by copper(II) cations. It can be assumed that $\mathrm{Cu}-\mathrm{cbc}$, as well as $\mathrm{mb}$, is a redox-active molecule. The $\mathrm{Cu}$-dependent oxidase activity of $\mathrm{mb}$ take place in the reduction of $\mathrm{O}_{2}$ to $\mathrm{O}_{2}{ }^{-}$with either NADH or duroquinol as a reductant. The chemical or biological dismutation of superoxide to hydrogen peroxide was proposed [6]. The hydrogen peroxide reductase activity of mb was shown. In the presence of a reductant, $\mathrm{H}_{2} \mathrm{O}_{2}$ was reduced by $\mathrm{Cu}-\mathrm{mb}$. Similar properties are also characteristic of cbc from both M. capsulatus Bath and M. album BG8 [6]. Assuming that Cu-cbc from M. capsulatus (M) possesses resembling properties and can form superoxide radical and hydrogen peroxide, this can form a basis of the mechanism of the catalytic activity of $\mathrm{Cu}-\mathrm{cbc}$ in the oxidation of $\mathrm{H}_{2} \mathrm{~A}$ by oxygen.

The oxidation rate $\left(w_{\mathrm{H} 2 \mathrm{~A}}\right)$ and half-rotation time $\left(t_{1 / 2}\right)$ of $\mathrm{H}_{2} \mathrm{~A}$ oxidation by hydrogen peroxide in the presence of $\mathrm{Cu}$-cbc is lower compared to a similar reaction in the absence of $\mathrm{Cu}$-cbc (Table 1 ). In addition, deviations from the kinetic curve of $\mathrm{H}_{2} \mathrm{~A}$ oxidation from the law of the first order are observed. At small times of transformation of $\mathrm{H}_{2} \mathrm{~A}, k_{\text {obs }}$ was $20 \%$ more than at large times. These deviations can be satisfactorily described by taking the first-order decomposition of hydrogen peroxide with an effective velocity constant of the order of $50 \times 10^{-4} \mathrm{~s}^{-1}$. The initial value of $k_{o b s}=12.4 \times 10^{-4} \mathrm{~s}^{-1}$ is $30 \%$ less than its value when $\mathrm{H}_{2} \mathrm{~A}$ is oxidized with hydrogen peroxide in a non-metal system. This unexpected result means that the $\mathrm{Cu}-\mathrm{cbc}$ complex can somehow effectively bind intermediate active particles under the conditions of $\mathrm{H}_{2} \mathrm{~A}$ by hydrogen peroxide oxidation and use them primarily for the catalytic reaction of hydrogen peroxide decomposition. Note that copper (II) cations in the solution at the concentration used are not active in the decomposition of hydrogen peroxide and practically do not change its concentration. Thus, we can make an assumption about the high affinity of the Cu-cbc complex to ROS. This may be the reason for the increased rate of methane hydroxylation by pMMO in the presence of $\mathrm{Cu}$-cbc due to the availability of active oxygen-containing copper complexes for a small molecule $\mathrm{CH}_{4}[12]$.

The biosynthesis of cbc from M. capsulatus (M) depends on the level of copper in the growth medium. An increase in the secretion of $c b c$ to the growth medium is observed at an increased copper content in the growth medium [31]. As iron, copper in oxygen-containing solutions can generate various toxic ROS via the Fenton and Haber-Weiss reactions $[1,28]$. The formation of ROS is also observed due to the active metabolism of methanotrophs [3]. The ROS levels in cells are maintained in physiological limits by the functioning of specialized protection systems of catalase, superoxide dismutase, cytochrome $c$ peroxidase, glutathione peroxidase, and free glutathione [3]. Genes that encode catalase are absent from the genome relative to M. capsulatus (M) and well-studied methanotroph M. capsulatus Bath [3,32]. No catalase activity was observed for M. szegediense O-12 [3]. Genome M. capsulatus Bath contains the gene that encodes glutathione peroxidise [32]. Bacterial cytochrome $c$ peroxidase in $M$. capsulatus Bath involved in the detoxication of hydrogen peroxide by reducing the latter to water was characterized $[3,33]$. The obtained results suggest that the cbc not only binds copper, thus diminishing its toxicity, but also the $\mathrm{Cu}$-cbc complex can participate, along with the enzymatic antioxidant systems of methanotrophs, in ROS detoxication caused by an increased copper 
content in the growth medium and the metabolism of methanotrophs. The mechanism of the action of $\mathrm{Cu}-\mathrm{cbc}$ in the oxidation of $\mathrm{H}_{2} \mathrm{~A}$ will be elucidated elsewhere.

\section{Conclusions}

The biological and physiological properties and functions of $\mathrm{mb}$, different chalkophores and copper-binding compounds ( $\mathrm{cbc}$ ) are probably wider than it seems at first glance. It was shown, for the first time, that the copper complex with the cbc from M. capsulatus (M), depending on the nature of the oxidant (oxygen or hydrogen peroxide), can show different properties in reactions of $\mathrm{H}_{2} \mathrm{~A}$ oxidation. Namely, the rate constant of $\mathrm{H}_{2} \mathrm{~A}$ oxidation in the presence of the copper complex of cbc from $M$. capsulatus $(\mathrm{M})$ by air oxygen was shown to be 1.5 times higher, but it is decreased by almost one-third in oxidation by hydrogen peroxide compared than that of the noncatalytic reactions. This indirectly indicates that the cbc can participate in the detoxication of the reduction products of molecular oxygen, in particular, the formed hydrogen peroxide, which is reduced to water. Thus, the $c b c$ is mimetic ascorbate oxidase in the oxidation of $\mathrm{H}_{2} \mathrm{~A}$ by molecular oxygen.

Supplementary Materials: The following are available online at http://www.mdpi.com/2313-7673/5/4/48/s1, Figure S1: Change in fluorescence spectra during titration of stock solutions of cbc from M. capsulatus (M) with a solution of copper sulfate; Figure S2: Absorption changes at $265 \mathrm{~nm}$ registered for the oxidation of a solution of $\mathrm{H}_{2} \mathrm{~A}\left(c^{0}=7 \times 10^{-5} \mathrm{~mol} \mathrm{~L}^{-1}\right)$.

Author Contributions: L.V.A. and R.I.G. conceived and designed the experiments; L.V.A. wrote the paper. All authors have read and agreed to the published version of the manuscript.

Funding: This research was carried out in the framework of the state task (No. 0089-2019-0004, No. AAAA-A19-119071190045-0).

Conflicts of Interest: The authors declare no conflict of interest. The funders had no role in the design of the study; in the collection, analyses, or interpretation of data; in the writing of the manuscript, or in the decision to publish the results.

\section{References}

1. DiSpirito, A.A.; Semrau, J.D.; Murrell, J.C.; Gallagher, W.H.; Dennison, C.; Vuilleumier, S. Methanobactin and the link between copper and bacterial methane oxidation. Microbiol. Mol. Biol. Rev. 2016, 80, 387-409. [CrossRef] [PubMed]

2. Miyaji, A.; Suzuki, M.; Baba, T.; Kamachi, T.; Okura, I. Hydrogen peroxide as an effecter on the inactivation of particulate methane monooxygenase under aerobic conditions. J. Mol. Catal. B-Enzym. 2009, 57, 211-215. [CrossRef]

3. Medvedkova, K.A.; Khmelenina, V.N.; Suzina, N.E.; Trotsenko, Y.A. Antioxidant systems of moderately thermophilic methanotrophs Methylocaldum szegediense and Methylococcus capsulatus. Microbiology 2009, 78, 670-677. [CrossRef]

4. Kim, K.; Portis, A.R., Jr. Oxygen-dependent $\mathrm{H}_{2} \mathrm{O}_{2}$ production by Rubisco. FEBS Lett. 2004, 571, $124-128$. [CrossRef] [PubMed]

5. Medvedkova, K.A.; Khmelenina, V.N.; Baskunov, B.P.; Trotsenko, Y.A. Synthesis of melanin by a moderately thermophilic methanotroph Methylocaldum szegediense depends on cultivation temperature. Microbiology 2008, 77, 112-114. [CrossRef]

6. Choi, D.W.; Semrau, J.D.; Antholine, W.E.; Hartsel, S.C.; Anderson, R.C.; Carey, J.N.; Dreis, A.M.; Kenseth, E.M.; Renstrom, J.M.; Scardino, L.L.; et al. Oxidase, superoxide dismutase, and hydrogen peroxide reductase activities of methanobactin from types I and II methanotrophs. J. Inorg. Biochem. 2008, 102, 1571-1580. [CrossRef]

7. Semrau, J.D.; DiSpirito, A.A.; Gu, W.; Yoon, S. Metals and methanotrophy. Appl. Environ. Microbiol. 2018, 84, e02289-17. [CrossRef]

8. Khmelenina, V.N.; Rozova, O.N.; But, C.Y.; Mustakhimov, I.I.; Reshetnikov, A.S.; Beschastnyi, A.P.; Trotsenko, Y.A. Biosynthesis of secondary metabolites in methanotrophs: Biochemical and genetic aspects (Review). Appl. Biochem. Microbiol. 2015, 51, 150-158. [CrossRef] 
9. Choi, D.W.; Bandow, N.L.; McEllistrem, M.T.; Semrau, J.D.; Antholine, W.E.; Hartsel, S.C.; Gallagher, W.; Zea, C.J.; Pohl, N.L.; Zahn, J.A.; et al. Spectral and thermodynamic properties of methanobactin from $\gamma$-proteobacterial methane oxidizing bacteria: A case for copper competition on a molecular level. J. Inorg. Biochem. 2010, 104, 1240-1247. [CrossRef]

10. Lu, X.; Gu, W.; Zhao, L.; Haque, M.F.U.; DiSpirito, A.A.; Semrau, J.D.; Gu, B. Methylmercury uptake and degradation by methanotrophs. Sci. Adv. 2017, 3, e1700041. [CrossRef]

11. Zahn, J.A.; DiSpirito, A.A. Membrane-associated methane monooxygenase from Methylococcus capsulatus (Bath). J. Bacteriol. 1996, 178, 1018-1029. [CrossRef] [PubMed]

12. Choi, D.W.; Antholine, W.E.; Do, Y.S.; Semrau, J.D.; Kisting, C.J.; Kunz, R.C.; Campbell, D.; Rao, V.; Hartsel, S.C.; DiSpirito, A.A. Effect of methanobactin on the activity and electron paramagnetic resonance spectra of the membrane-associated methane monooxygenase in Methylococcus capsulatus Bath. Microbiology 2005, 151, 3417-3426. [CrossRef] [PubMed]

13. Avdeeva, L.V.; Tukhvatullin, I.A.; Gvozdev, R.I. Optimization cultivation of bacteria Methylococcus capsulatus (M) for production methanobactin. Nat. Tech. Sci. 2015, 11, 132-136. (In Russian)

14. Avdeeva, L.; Tukhvatullin, I.; Gvozdev, R. Isolation and purification of methanobactin from Methylococcus capsulatus (M). FEBS J. 2013, 280, 101-102.

15. Avdeeva, L.V.; Goryachev, N.S.; Gvozdev, R.I. Spectral-fluorescent properties of methanobactin from Methylococcus capsulatus (strain M). Acta Nat. 2016, 2, 95. (In Russian)

16. Pozin, M.E. Hydrogen Peroxide and Peroxide Compounds; Goskhimizdat: Moscow, Russia, 1951; p. 475. (In Russian)

17. Solomonov, A.V.; Rumyantsev, E.V.; Kochergin, B.A.; Antina, E.V. The kinetics of oxidation of bilirubin and ascorbic acid in solution. Russ. J. Phys. Chem. A 2012, 86, 1048-1052. [CrossRef]

18. Dawson, R.; Elliot, D.; Elliot, W.; Jones, K. Data for Biochemical Research; Clarendon: Oxford, MS, USA, 1986; p. 429.

19. Yatsimirsky, V.K.; Geraseva, V.G.; Bezuglaya, T.N.; Diyuk, V.E. Oxidation of ascorbic acid by molecular oxygen in the presence of heterobimetallic complexes of copper. Ukr. Chem. J. 2009, 75, 43-48. (In Russian)

20. Miyake, N.; Kim, M.; Kurata, T. Formation mechanism of monodehydro-l-ascorbic acid and superoxide anion in the autoxidation of l-ascorbic acid. Biosci. Biotechnol. Biochem. 1997, 61, 1693-1695. [CrossRef]

21. Khan, M.M.T.; Martell, A.E. Metal ion and metal chelate catalyzed oxidation of ascorbic acid by molecular oxygen. I. Cupric and ferric ion catalyzed oxidation. J. Am. Chem. Soc. 1967, 89, 4176-4185. [CrossRef]

22. Moya, H.D.; Coichev, N. Kinetic studies of the oxidation of L-ascorbic acid by tris(oxalate)cobaltate in the presence of CDTA metal ion complexes. J. Braz. Chem. Soc. 2006, 17, 364-368. [CrossRef]

23. Khan, M.N.; Sarwar, A. The influence of transition metal ions on the kinetics of ascorbic acid oxidation by methylene blue in strongly acidic media. Turk. J. Chem. 2001, 25, 433-440.

24. Sailani, R.; Dubey, S.; Khandelwal, C.L.; Sharma, P.D.; Khan, P. Kinetics and mechanism of oxidation of L-ascorbic acid by peroxomonosulphate in acid perchlorate medium. Role of copper (II) as a trace metal-ion catalyst. CR Chim. 2011, 14, 1088-1094. [CrossRef]

25. Mishra, D.K.; Dhas, T.P.A.; Sharma, P.D.; Bhargava, A.P.; Gupta, Y.K. Role of trace metal ions. Kinetics and mechanism of the copper(II)-catalysed oxidation of ascorbic acid with peroxodiphosphate in acetate buffers. J. Chem. Soc. Dalton Trans. 1990, 4, 1265-1270. [CrossRef]

26. Zhang, G.-F.; Chen, H.-Y. Chemiluminescence studies of the oxidation of ascorbic acid with copper(II) catalyzed by halide anions and its application to the determination of halide anions and ascorbic acid. Anal. Sci. 2000, 16, 1317-1321. [CrossRef]

27. Bayr Hülya, M.D. Reactive oxygen species. Crit. Care Med. 2005, 33, 498-501. [CrossRef] [PubMed]

28. Davies, M.B. Reactions of L-ascorbic acid with transition metal complexes. Polyhedron 1992, 11, $285-321$. [CrossRef]

29. Maksimov, A.L.; Kardasheva, Y.S.; Predeina, V.V.; Kluev, M.V.; Ramazanov, D.N.; Talanova, M.Y.; Karakhanov, E.A. Iron and copper complexes with nitrogen-containing ligands as catalysts for cyclohexane oxidation with hydrogen peroxide under mild reaction conditions. Petrol. Chem. 2012, 52, 318-326. [CrossRef]

30. Shul'pina, L.S.; Takaki, K.; Strelkova, T.V.; Shul'pin, G.B. Benzene oxidation with hydrogen peroxide catalyzed by soluble and heterogenized copper compounds. Petrol. Chem. 2008, 48, 219-222. [CrossRef]

31. Avdeeva, L.; Gvozdev, R. Effect of copper concentration on the growth of Methylococcus capsulatus (strain M). Chem. J. Mold. 2017, 12, 110-114. [CrossRef] 
32. Ward, N.; Larsen, Q.; Sakwa, J.; and 39 coauthors. Genomic insights into methanotrophy: The complete genome sequence of Methylococcus capsulatus (Bath). PLoS Biol. 2004, 2, 1616-1628. [CrossRef]

33. Zahn, J.A.; Arciero, D.M.; Hooper, A.B.; Coats, J.R.; Dispirito, A.A. Cytochrome $c$ peroxidase from Methylococcus capsulatus Bath. Arch. Microbiol. 1997, 168, 362-372. [CrossRef] [PubMed] 